Goldschmidt 2021 Abstract

https://doi.org/10.7185/gold2021.5732

\section{Incipient melting of the mantle transition zone: experimental insight on kimberlite genesis \\ PIERRE CONDAMINE ${ }^{1}$, SUMITH ABEYKOON ${ }^{2}$ AND DANIEL FROST ${ }^{2}$ \\ ${ }^{1}$ CRPG-CNRS \\ ${ }^{2}$ University of Bayreuth \\ Presenting Author: pierre.condamine@univ-lorraine.fr}

The mantle transition zone $(410-660 \mathrm{~km})$ is often proposed to be an important water repository in the Earth's mantle and a low velocity layer attributed to the presence of a partially (lowdegree) molten hydrated layer has been suggested to exist atop the $410 \mathrm{~km}$ discontinuity where it may reside due to neutral melt buoyancy. Previous studies have indeed proposed that ascending ambient mantle may undergo hydrous partial melting as it rises out of the transition zone at $410 \mathrm{~km}$ owing to a decrease in the $\mathrm{H}_{2} \mathrm{O}$ storage capacity of olivine compared to wadsleyite. The buoyancy of such a melt layer (i.e., its density compared to the surrounding mantle) will be controlled by its chemical composition. On the other hand, ringwoodite inclusions in diamonds brought to the surface by kimberlite magmas may support the presence of deep-rooted melts that can ascent to the Earth's surface. To date no experimental study has examined the possible composition of low-degree melts at transition zone depths or their associated buoyancy.

Here we performed multi-anvil experiments using an iterative procedure to determine the incipient melt composition of a peridotite assemblage at mantle transition zone conditions (17 $\left.\mathrm{GPa}, 1600{ }^{\circ} \mathrm{C}\right)$. A high proportion of glass (50-70 wt. \%) is added to the peridotite to ensure melt pool separation. Large degrees of melt make the determination of melt $\mathrm{H}_{2} \mathrm{O}$ contents by mass balance more accurate.

While almost all the inserted melt composition was recrystallizing during the first iterations, nearly all the melt is still present at the end of the experiment in the last iterations, indicating near-equilibrium conditions. The final melt is in equilibrium with a typical peridotite assemblage containing wadsleyite, garnet and pyroxene. It was possible to saturate a large melt pool for which the $\mathrm{H}_{2} \mathrm{O}$ content can be accurately determined by mass balance with a transition zone mineral assemblage. The melt is strongly silica-undersaturated (35 wt. \% $\mathrm{SiO}_{2}$ ) together with high amounts of $\mathrm{MgO}(27$ wt. \%) and $\mathrm{CaO}$ (13 wt. \%) whereas being depleted in $\mathrm{Al}_{2} \mathrm{O}_{3}$ (1 wt. \%). These features are nearly identical to diamond-bearing kimberlite rocks.

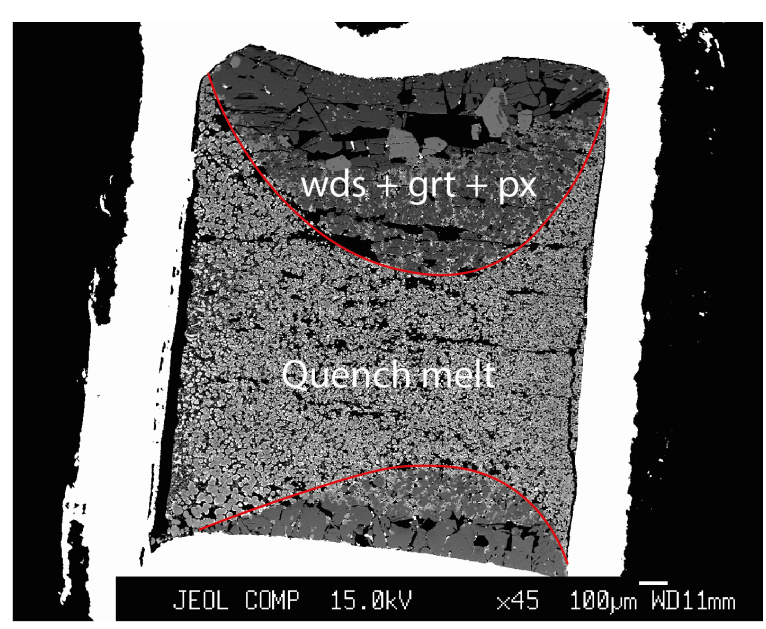

